\title{
Labour
}

Journal of Canadian Labour Studies

Le Travail

Revue d'Études Ouvrières Canadiennes

\section{Work Incentives for "Welfare Mothers" in 1970s Ontario Screening Out the Political}

\section{Wendy McKeen}

Volume 85, printemps 2020

URI : https://id.erudit.org/iderudit/1070905ar

DOI : https://doi.org/10.1353/1lt.2020.0004

Aller au sommaire du numéro

Éditeur(s)

Canadian Committee on Labour History

ISSN

0700-3862 (imprimé)

1911-4842 (numérique)

Découvrir la revue

Citer cet article

McKeen, W. (2020). Work Incentives for "Welfare Mothers" in 1970s Ontario: Screening Out the Political. Labour / Le Travail, 85, 91-125.

https://doi.org/10.1353/llt.2020.0004

\section{Résumé de l'article}

Cet article analyse la politique entourant l'introduction des mesures d'incitation au travail pour les «mères aidantes» en Ontario dans les années 1970 et au début des années 1980. Il utilise la théorie de la gouvernance et de l'assemblage pour analyser la substance et la dynamique des débats dans ce domaine, car ils impliquaient des représentants de l'État, des défenseurs de la politique sociale et de la protection sociale et des mères activistes. À l'aide d'un large éventail de documents d'archives et de comptes rendus des médias, l'article révèle les pratiques discursives et autres que les fonctionnaires ont utilisées pour contenir le débat et exclure des possibilités plus radicales, ainsi que le rôle que les groupes progressistes ont parfois joué dans le renforcement de la compétence officielle. L'article conclut que les mesures d'incitation au travail pour les mères aidantes n'étaient pas seulement des politiques bénignes mais des mécanismes qui filtraient le politique et, en fin de compte, rendaient les mères aidantes encore plus démunies et marginalisées. De tels programmes fonctionnent à ce jour pour renforcer une vision du monde qui ignore l'oppression structurelle et l'inégalité.
Ce document est protégé par la loi sur le droit d'auteur. L’utilisation des services d'Érudit (y compris la reproduction) est assujettie à sa politique d'utilisation que vous pouvez consulter en ligne.

https://apropos.erudit.org/fr/usagers/politique-dutilisation/ 


\section{Work Incentives for "Welfare Mothers" in 1970s Ontario: Screening Out the Political} Wendy McKeen

FEMINIST POLITICAL ECONOMISTS have written extensively on the decline of women's social rights, particularly with regard to the treatment of single mothers on welfare. This work has attributed the way that single mothers have been oppressed under welfare policy to built-in gender biases that fail to recognize their unpaid care work. ${ }^{1}$ This article contributes further to understanding the roots of this decline by examining the political struggle over the

1. For example, see Krystle Maki, "Neoliberal Deviants and Surveillance: Welfare Recipients Under the Watchful Eye of Ontario Works," Surveillance and Society 9,1 (2011): 47-63; Patricia Evans, "Single Mothers and Ontario's Welfare Policy: Restructuring the Debate," in Janine Brodie, ed., Women and Canadian Public Policy (Toronto: Harcourt Brace and Company, 1996), 151-171; Amber Gazso, “Gendering Social Assistance Reform," in Daniel Béland \& PierreMarc Daigneault, eds., Welfare Reform in Canada: Provincial Social Assistance in Comparative Perspective (Toronto: University of Toronto Press, 2015), 273-287; Janet Mosher, "Human Capital and the Post-Scripting of Women's Poverty," in Beth Goldblatt \& Lucie Lamarche, eds., Women's Rights to Social Security and Social Protection (Oxford: Hart Publishing, 2014); Katherine Scott, "The Dilemma of Liberal Citizenship: Women and Social Assistance Reform in the 1990s," Studies in Political Economy 50, 1 (1996): 7-36; Margaret Little, "No Car, No Radio, No Liquor Permit": The Moral Regulation of Single Mothers in Ontario, 1920-1997 (Don Mills, ON: Oxford University Press, 1998); Little, “Just Another Neoliberal Worker: Tracing the State's Treatment of Low-Income Mothers," International Journal of Sociology of the Family 38, 1 (2012): 1-17; Little, "A Litmus Test for Democracy: The Impact of Ontario Welfare Changes on Single Mothers," Studies in Political Economy 66, 1 (2001): 9-36; Tracy Smith-Carrier, "Reproducing Social Conditions of Poverty: A Critical Feminist Analysis of Social Assistance Participation in Ontario, Canada," Journal of Women, Politics, and Policy 23, 4 (2017): 98-521; Margaret Little \& Lynne Marks, "Ontario and British Columbia Welfare Policy: Variants on a Neoliberal Theme," Comparative Studies of South Asia, Africa, and the Middle East 30, 2 (2010): 192-203.

Wendy McKeen, “Work Incentives for 'Welfare Mothers' in 1970s Ontario: Screening Out the Political,” Labour/Le Travail 85 (Spring 2020): 91-125, https://doi.org/10.1353/llt.2020.0004. 
issue of work incentives for "welfare mothers." While many scholars have identified the neoliberal mid-1990s as the period in which the Ontario government reclassified single mothers on welfare as employable and subject to work requirements, in reality the Ontario government began promoting this policy in the early 1970s - and it is on this decade that the article focuses.

Much of the existing research on this period of social assistance reform and its relevance to women has been from a political economy perspective. ${ }^{3}$ Research on the emergence of "workfare" in Canada has also often drawn from this tradition and examined the macro-level variables that influenced its adoption. ${ }^{4}$ For example, Jamie Peck has argued that the rise in neoliberalism and neoconservatism was a pivotal influence on Canada's embrace of workfare, as were the influence of US policy discourse and the shift toward decentralization of social policy from the federal to provincial governments. ${ }^{5} \mathrm{~W}$ ith respect to Ontario's embrace of work incentives for welfare mothers, Patricia Evans argues that economic crises and fiscal pressures on the government were criti$\mathrm{cal}$, along with such factors as the rising number of single mothers on social assistance, the influence of feminism, and the increased acceptance of, and growth in, maternal employment. ${ }^{6}$ Other scholars explain this phenomenon by focusing on cultural shifts; for example, Amber Gazso emphasizes the influence of shifts in the "culture of mothering." While these analyses are important, they give little attention to political agency and historical struggles over discourse and meaning, including, especially, the impact that activist welfare mother groups have had in shaping the debate in this area.

2. Lone mother welfare recipients were often referred to as "welfare mothers" in this period, and thus I use the term in this article.

3. For example, see, Little, "No Car"; Alvin Finkel, Social Policy and Practice in Canada A History (Waterloo: Wilfred Laurier University Press, 2006); James Struthers, The Limits of Affluence: Welfare in Ontario, 1920-1970 (Toronto: University of Toronto Press and Province of Ontario, 1994).

4. "Workfare" refers to the shift in social assistance that occurred in late 1980s/early 1990s in many countries whereby the receipt of welfare benefits became tied to their willingness to participate in programs designed to increase their "employability," in an attempt by governments to encourage the movement of individuals from welfare to paid work.

5. Jamie Peck, Workfare States (New York: Guilford, 2001). See also Maureen Baker \& David Tippen, Poverty, Social Assistance, and the Employability of Mothers (Toronto: University of Toronto Press, 1999).

6. Patricia Evans, "Work Incentives and the Single Mother: Dilemmas of Reform," Canadian Public Policy/Analyse de Politiques 14, 2 (1988): 126, 128; see also Scott, "Dilemma of Liberal Citizenship." On the shifting poverty discourse in the US context, see Alice O'Connor, Poverty Knowledge: Social Science, Social Policy, and the Poor in Twentieth-Century U.S. History (Princeton: Princeton University Press, 2001).

7. Amber Gazso, "Moral Codes of Mothering and the Introduction of Welfare-to-Work in Ontario," Canadian Review of Sociology/Revue canadienne de sociologie 49, 1 (2012): 26-49. 
This article seeks to address this gap by examining in detail the content and dynamics of struggle over the issue of work incentives for welfare mothers that took place in Ontario in the 1970s and early 1980s. Various actors were involved in this debate, including both powerful interests (primarily government) and more marginalized and oppositional actors (primarily a progressive social policy sector made up of social policy and social service advocacy groups, feminists, and activist welfare mother groups). The article poses questions and uses tools drawn mainly from poststructural and governance theory and, specifically, from the work of Sanford Schram on contemporary poverty research, Nancy Fraser on the politics of needs interpretation, and Tania Murray Li on practices of assemblage and government improvement schemes. ${ }^{8}$ These works are concerned with understanding the mechanisms by which governments rule and govern, especially in relation to "difficult" populations, and within this, how it is that some ideas are brought to the fore and normalized while others are foreclosed and seemingly lost. Drawing from Li's concept of generic "practices of assemblage," this article seeks to identify the practices used by government actors to contain and depoliticize the debate on work incentives for welfare mothers and the implications this had for the government's ability to manage this population while avoiding many of the reforms that welfare mothers and their allies sought and foreclosing the alternative and more radical perspectives advanced by oppositional groups - not least, welfare mother activists.

The article comprises four parts. Part one expands on the theoretical/ methodological approach and research material used in this study. Part two provides background on, and an overview of, the debate on the issue of work incentives for welfare mothers that took place in Ontario during the 1970s and early 1980s. This includes a focus on the broader conditions that encouraged this ideological and policy turn, the political and policy choices made by the Ontario government in this area, and the nature of the progressive oppositional sector in this debate and its reactions to this issue. I argue that welfare mothers themselves were an important part of this oppositional sector. Welfare mother groups brought their own interpretations of the "needs" of welfare mothers - one of them being that welfare mothers were deserving of income support benefits "in the here and now" on the grounds that their poverty was the result of systemic, historical inequalities and biases in the first place and that they were already performing valuable work for society as mothers.

8. Sanford Schram, Words of Welfare: The Poverty of Social Science and the Social Science of Poverty (Minneapolis: University of Minnesota Press, 1995); Nancy Fraser, "Struggle over Needs: Outline of a Socialist-Feminist Critical Theory of Late-Capitalist Political Culture," in Linda Gordon, ed., Women, the State, and Welfare (Madison: University of Wisconsin Press, 1990); Tania Murray Li, The Will to Improve: Governmentality, Development, and the Practice of Politics (Durham: Duke University Press, 2007); Li, "Practices of Assemblage and Community Forest Management," Economy and Society 36, 2 (2007): 263-293. 
Part three of the article investigates one aspect of the political struggle over the issue of work incentives for welfare mothers: the Ontario government's early attempt to shape the discourse in this area. An examination of a key report authorized by the Ontario government on the problem of welfare mothers reveals the limited understanding of the issue at this time, including the conceptualization of single mothers on welfare as dependent, an underclass, and subjects for whom the only solution was to leave welfare for paid employment (even if it meant continued poverty).

In part four, the article turns to how situated government actors handled resistance to and criticism of the government's agenda. Borrowing from Li's concept of practices of assemblage as well as political-economic theory, it uncovers the efforts government officials made to manage and contain the debate, cover over the contradictions that their model entailed, and counter any attempts to upset the assemblage and addresses how their actions served to legitimate and validate the government's preferred work incentives/low welfare benefits paradigm while screening out alternative understandings. Also revealed is the way that some progressive actors aided in solidifying the dominant assemblage through their roles as "friendly critics." The article concludes that rather than improving the lives of welfare mothers and their children, government practices and policies in this area served to disempower welfare mothers and to preserve and expand the state's own power and, ultimately, that of capitalism, neoliberalism, patriarchy, and male privilege. These findings also shed light on why activation policies continue to be taken for granted as the best solution for lone mothers on welfare even when it is known that this approach fails women and their families and perpetuates and reentrenches inequality.

\section{Theoretical Approach}

A LARGE PART OF THE HISTORY of social policy and welfare politics in Ontario, as elsewhere, entails struggle over meaning and ideas. One of the ways to better understand how and why work incentives became the accepted policy paradigm for addressing the problem of welfare mothers is to uncover the messy realities of actors in struggle and the ways situated actors were able to bring certain ideas and discourses to the fore while foreclosing others. Poststructural theory, notably governance and assemblage theory, offers important critical tools in this respect. These theoretical approaches share an understanding that policies are not just responses to problems "out there" but are themselves a means for constructing the very problems they seek to address. In other words, policies can serve to reproduce oppressive social relations. Governance theory takes a particular interest in both the role of expert discourse or knowledge in shaping debates on social policy and the limitations and repressive aspects of such knowledge. Schram's analysis of contemporary welfare research in the US context is a case in point. He contends that welfare 
research is written in an economistic-therapeutic-managerial (ETM) discourse that reinforces state interests in how to understand "the poor." Specifically, ETM discourse "imputes to the poor the identity of self-interested, utility-maximizing individuals who need to be given the right incentives so that they will change their behavior and enable the state to manage better the problems of poverty and welfare dependency." 9 This body of research focuses almost exclusively on individual behaviour as a way to understand the causes of poverty. It assumes poor people are passive and dysfunctional and need to be managed and rehabilitated into becoming more economically productive. ${ }^{10}$

Fraser, sharing a somewhat similar understanding of the role of expert discourse in shaping politics, has focused on what she refers to as the "politics of needs interpretation" and, specifically, "expert needs discourses." ${ }^{11}$ She argues that expert-needs discourse entails the work by specialized dominant groups (usually the state) to translate politicized needs (i.e. needs that are often politicized from below, usually by social movements - for example, the right to welfare benefits on the basis of need) into administrative discourses (i.e. administrative problems to be solved and ostensibly understood as a general state of affairs that could, in principle, befall anyone). ${ }^{12}$ When this discursive shift happens, the issues of the people whose needs are in question (in this case, welfare recipients) become both decontextualized (or represented in abstraction from class, race, and gender hierarchy) and reconceptualized in ways that tacitly presuppose entrenched background institutions, such as wage labour, privatized child rearing, and gender-based separation. Through this process, the people affected are screened of human agency and repositioned as not only passive recipients but also rational utility maximizers and manipulable objects.

The concept of assemblage adds to this framework for critiquing the discursive operations of governance. "Assemblage" does not reference a particular arrangement, whole, or essence (such as the institutional apparatus of "the state") but rather refers to the interaction of parts (across orders of the material, the discursive, and the subject) to produce social formation (keeping in mind that any actualization might be otherwise)..$^{13}$ This idea aligns with the understanding within governance theory that "the state" is not an object but sets of practices, techniques, discourses, and forms of expertise and knowledge concerned with defining the proper and legitimate orientation and conduct

9. Schram, Words of Welfare, 4.

10. Schram, Words of Welfare, 5.

11. Fraser, "Struggle over Needs."

12. Fraser, "Struggle over Needs," 212.

13. Ian McGimpsey, "Late Neoliberalism: Delineating a Policy Regime," Critical Social Policy 37, 1 (2017): 64-84. 
of citizens, including their identities and subjectivities (i.e. aspirations, needs, desires, capacities, and lifestyles). ${ }^{14}$

Li's discussion of assemblage intersects with many of these ideas, and her work is particularly useful for studying the governance of populations deemed to be in need of "improvement." According to $\mathrm{Li}$, assemblage denotes the ways that heterogeneous elements can be brought together to constitute a technical field to be governed and "improved." ${ }^{15}$ As she explains, the elements of an assemblage are mostly drawn from an existing repertoire and are a matter of habit, accretion, and bricolage. ${ }^{16}$ Further, assembly involves both a practice ("to assemble") and agency - the hard work necessary to secure assemblages that is often done by situated individuals.

Li views government schemes for improving the well-being of populations as assemblages and as a form of expert knowledge. As expert knowledge, such schemes identify the problems that need to be rectified, render them techni$\mathrm{cal}$, and devise a narrative that connects the proposed interventions to the problems they will solve. In this sense, these schemes operate as "anti-politics" machines that repose political questions as technical problems responsive to technical intervention. Li stresses that part of what makes an improvement scheme operate effectively is its ability to absorb critique within the realm of expertise. "The endless deferral of the promise [of improvement] ... to the time when the ultimate strategy is devised and implementation perfected does more than enable the [improvement] ... apparatus to sustain itself," she argues. "It maintains the divide that separates trustees from their wards. It keeps the attention of many critics focused on the deficiencies of such schemes and how to correct them."17

Together these theories provide a critical lens for analyzing the politics of work incentives for welfare mothers. They pose a critical question: In what ways and to what degree did this policy agenda and the discourse surrounding it serve to reinforce and legitimize the role of a powerful elite to manage and contain a difficult population and to rule out new potentialities that ran counter to elite interests and the existing neoliberal, capitalist, patriarchal regime?

14. Mitchell Dean, "Governing the Unemployed Self in an Active Society," Economy and Society 24, 4 (1995): 559-583.

15. Li, Will to Improve; Li, "Practices of Assemblage."

16. Li, "Practices of Assemblage," 265. "Bricolage" refers to the action of coming to know/ learn through the "piecing together" done by actors of what they know from different sources. A bricoleur continually acquires and assembles tools and materials, keeping them until they might be used. It also entails the idea that the purpose itself is partly shaped by the tools and materials available. See Richard Freeman, "Epistemological Bricolage: How Practitioners Make Sense of Learning," Administration and Society 39, 4 (2007): 485-486.

17. Li, "Practices of Assemblage," 276-277. 
Li has also provided insight into the mechanisms of assemblage in elaborating what she refers to as the generic "practices of assemblage" that are necessary for keeping any assemblage together. As she explains, these practices are often carried out by state actors and include the following: forging alignments, or linking together the objectives of various parties to the assemblage; rendering technical, or reducing the messiness of the social world to a diagram in which problem $\mathrm{A}$ and intervention $\mathrm{B}$ will produce beneficial result $\mathrm{C}$; authorizing knowledge, including specifying a body of knowledge, confirming enabling assumptions, and containing critiques; managing failures and contradictions by "presenting failure as the outcome of rectifiable deficiencies; smoothing out contradictions so that they seem superficial rather than fundamental; devising compromises"; engaging in anti-politics, or "reposing political questions as matters of technique; closing down debate about how and what to govern and the distributive effects of particular arrangements by reference to expertise; [and] encouraging citizens to engage in debate while limiting the agenda."18

$\mathrm{Li}$ also refers to the practice of "contained critique": a concept that shifts the focus onto the activities of the oppositional sector and social movements. Both Fraser and Li emphasize that debates over "the social" are highly complex struggles. Fraser sees them as often involving social movements that are seeking state provision but are also opposed to administrative and therapeutic interpretations of need. In her view, expert discourses sometimes contain critical segments that act as "bridging" discourses that loosely link social movements with the social state. ${ }^{19}$ Similarly, Li argues that "many actors share the will to improve" and that, in practice, contradictions within assemblages are often managed when parties make compromises; when this happens, the positions of oppositional actors can become compromised, and their critiques "contained." 20

In this article I will apply these theories - particularly Li's practices of assemblage - to help uncover the political agency and complex processes that were integral to the politics that surrounded the work incentives for welfare mothers agenda in 1970s Ontario, including the sidelining of alternative approaches advanced by welfare mothers themselves. Indeed, my intent is to examine how, and to what degree, the actions and discourses of situated individuals, especially those within the Ontario government, aligned with the kinds of assembly practices that Li has identified and therefore operated as hidden-hand mechanisms to repress alternative understandings and potentialities.

18. Li, "Practices of Assemblage," 284. Li puts forward a final practice of assemblage:

"reassembling," which is concerned with "grafting on new elements onto the assemblage, reworking existing elements for new purposes and transposing the meanings of key terms" (p. 284).

19. Fraser, "Struggle over Needs," 212.

20. Li, "Practices of Assemblage," 279. 
This study is based on an extensive body of archival documents retrieved from the collections of various government and non-governmental organizations and groups that were active in this debate, particularly the Ontario Ministry of Community and Social Services (MCSs) and related departments/ branches (e.g. Policy Secretariat, Strategic Policy and Planning Secretariat). This material was composed of internal memos, press releases, ministers' speeches, policy documents, correspondence, and the briefs of advocacy groups. With respect to non-governmental organizations, materials were retrieved from the collections of the key social policy organizations, social advocacy groups, women's organizations, and welfare mother groups involved in the debates. I also drew from secondary sources of that period, including newspaper articles, legislative proceedings, and magazines and newsletters.

\section{Background and Overview}

THE REIMAgINING OF SINGLE MOTHERS on welfare as employable and, as such, subjects who should be incentivized to leave welfare for paid work was partly a reflection of major social, economic, political, and cultural shifts that took place in Canada in the late 1960s and early 1970s. First, the federal government's introduction in 1966 of a cost-sharing mechanism, the Canada Assistance Plan (CAP), which was part of its "war on poverty" thrust, led to a change in the way that single mothers were incorporated into social assistance programs. Up until 1967 in Ontario, single mothers were eligible to receive benefits under the Ontario Mothers' Allowance (OMA) program - a program that, despite its problems, recognized single mothers as a unique group with special needs and regulations. ${ }^{21}$ The OM A was dissolved with the introduction of CAP, and single mothers became clients of the newly formed Family Benefits Assistance (FBA) program, where they were classified together with other categories of recipients (such as the blind, disabled, and elderly) who were assumed to be (at least initially) long-term recipients and unemployable. ${ }^{22}$

21. Little, "No Car," 142. To be clear, a key problem of the omA was its anchor in maternalist and racist ideology that assumed the moral superiority of Protestant-Euro Canadian values and systematically excluded racialized, ethnic-minority, and Indigenous women (Little, "No Car," 9, 27, 31). Even after Indigenous women became eligible for welfare, the regulations and the racist attitudes of social workers ensured that few Indigenous women became beneficiaries. Women of ethnic-minority backgrounds, women migrants, and Indigenous women have continued to have difficulty accessing welfare benefits and to be stereotyped as undeserving and as the face of welfare abuse (pp. 175, 176). See also Sunera Thobani, Exalted Subjects: Studies in the Making of Race and Nation in Canada (Toronto: University of Toronto Press, 2007); Robyn Maynard, Policing Black Lives: State Violence in Canada From Slavery to the Present (Halifax: Fernwood, 2017).

22. Changes were made to Ontario's welfare system in 1967. On the first tier, the General Welfare Assistance (GWA) program, which was funded by federal, provincial, and municipal governments on a 50/30/20 basis and delivered by the municipal level, would remain as a program for short-term, "employable" recipients; that is, welfare benefits were conditional 
Secondly, the global economic shift of the mid-1970s ushered in an economic recession featuring rising inflation, high unemployment, and declining growth. Governments were faced with declining revenues and rising debt. ${ }^{23}$ Those in power increasingly saw social programs both as a source of work disincentives and as contributing to inflation. In Ontario, this culminated in a sharp turn by Bill Davis' Progressive Conservative government toward a neoliberal market-oriented austerity agenda. ${ }^{24}$ Several task forces that the government had struck set out a vision for reform that called for maximum expansion of and investment in the private sector, a reduction in public expenditures, and support for a residual social welfare system featuring an increase

on recipients making efforts to find employment and accepting employment offers. The new second tier was the Family Benefits Assistance (FBA) program, which was cost-shared by the federal and provincial governments on a 50/50 basis and delivered by the province; this was for categories of recipients considered to have long-term support needs and be "unemployable." Benefits under the FBA program were more generous than those under the GWA program. Ontario also made changes to its administrative structures responsible for administering social welfare policy, with the renaming of the Ontario Department of Public Works as the Department of Social and Family Services in 1967, and then as the Ministry of Community and Social Services in 1972. See Little, "No Car," 141; Allan Irving, From No Poor Law to the Social Assistance Review: A History of Social Assistance in Ontario, 1791-1987, Report No. RD44, Ontario Social Assistance Review, July 1987, 28.

23. James Rice, "Politics of Income Security: Historical Developments and Limits to Future Change," in Bruce Doern, ed., The Politics of Economic Policy (Toronto: University of Toronto Press, 1985), 221-250.

24. As Ramesh Mishra, Glenda Laws, and Priscilla Harding put it, "long before Reaganomics and Thatcherism came to symbolize a new departure in the social policy of Western countries and long before the Bennett government in British Columbia seemingly decided to move in that direction, the Province of Ontario had embarked on a program of downsizing government which, in retrospect, appears impressive in its candour and pioneering role." Mishra, Laws \& Harding, "Ontario," in Jacqueline Ismael, ed., Privatization and Provincial Social Services in Canada (Edmonton: University of Alberta Press, 1988), 123. According to Michael Prince, the restraint-oriented fiscal plan was put into effect from 1975 to 1978, at which point it was no longer seen as "good politics" owing to, for example, "fractious battles" over hospital closures; however, budgets remained preoccupied with fiscal restraint and economic stimulus during the 1981 to 1985 mandate. See Prince, "The Bland Stops Here: Ontario Budgeting in the Davis Era, 1971-1985," in Allan Maslove, ed., Budgeting in the Provinces: Leadership and the Premiers (Toronto: Institute of Public Administration in Canada, 1989), 87-119. Prince also notes that while the Progressive Conservatives returned with a minority government in 1975 (regaining majority status in 1981), with Stephen Lewis' New Democratic Party (NDP) holding the balance of power, the Davis government "was 'saved' when the NDP did not align themselves with the Liberals through an Accord, as they were to do formally in 1985" (p. 96). To be clear, the NDP, along with the progressive social policy community, actively opposed the Conservative government's regressive approach to social welfare policy. For example, NDP member of provincial parliament (MPP) Richard Johnson frequently confronted the Minister of Community and Social Services on issues of poverty and the decline in the value of welfare benefits during hearings of the Standing Committee on Social Development. Once elected in 1985, the coalition NDP/Liberal government raised social assistance rates by 25 per cent and, in 1986, announced an in-depth study of social welfare reform: the Social Assistance Review Committee. See Little, "No Car," 153-154. 
in for-profit services, a greater role for the voluntary sector, more emphasis on personal savings, the keeping of social assistance levels to a minimum, decentralization of services from the province to municipalities, and an embrace of the principle of work incentives. Social spending was cut significantly, and the provincial government began promoting an ethos of more individual and family-as opposed to government-responsibility for welfare. ${ }^{25}$ The government's focus effectively shifted from "tackling poverty" to "fixing welfare." 26

To be clear, this period also saw the beginnings of the emergence of a "new right" ideology in Ontario politics, especially by the late 1970s and early 1980s - an ideology that also became an undercurrent of social policy debate at this time. This voice was evident in the Toronto Sun's columns by journalist Claire Hoy and its letters to the editor. ${ }^{27}$ According to this view, government programs were too generous; they were replacing the role of family or community and undermining individual responsibility; social spending (for example, in the areas of childcare and welfare benefits) was coming at the expense of taxpayers; and welfare recipients had come to view welfare as "a career choice," "a way of life," and a right rather than a privilege. ${ }^{28}$ By the early 1980 s these ideas were being taken up by some within the Progressive Conservative Party of Ontario. For example, in 1983, then Ontario justice secretary Gordon Walker published a book, A Conservative Canada, in which he attacked big government and called for a return to a free-enterprise system, family values, the work ethic, and for workfare to replace welfare as a solution to the problem of "freeloaders" using the welfare system. ${ }^{29}$ As Allan Irving has also noted, the Ontario Conservative Party adopted a policy paper at a conference in September 1983 that argued government "should be leaner and meaner in providing social programs and in weaning people from a dependence on Government Services." 30

25. These principles were endorsed by two Ontario government task forces: the 1974 Task Force on Community and Social Services, chaired by Hugh Hanson, and the Report of the Special Program Review (the Henderson Report), published in 1975. See Irving, No Poor Law.

26. Peck, Workfare States, 92-93.

27. For example, as Claire Hoy wrote in one article, "the NDP attitude about welfare is disturbing, particularly the notion that people ... have no personal responsibility for [their] plight, that welfare is a right, and that society is at fault because these people left school early and got pregnant." See Hoy, "Single Mothers, Trying to Get Off Welfare," Toronto Sun, 30 April 1982 .

28. For example, Gord Walker, A Conservative Canada (Sutton West, ON: Paget Press, 1983), 146, 147 ("career choice"), cited by Irving, No Poor Law, 35; Drea quoted in Pat McNenly, “Ontario Lags on Welfare[,] Survey Shows," Toronto Star, 29 March 1982 ("a way of life").

29. Walker, A Conservative Canada; see Irving, No Poor Law, 35. See also Marvyn Novick, "Social Policy: The Search for a Provincial Framework," in Donald MacDonald, ed., Government and Politics of Ontario, 2nd ed. (Toronto: Van Nostrand Reinhold, 1980), 386.

30. Irving, No Poor Law, 36. 
A third major shift in this period that influenced the terms of debate was a dramatic rise in women's poverty, with single-mother families becoming a significant proportion of the poor. The number of families headed by single mothers receiving welfare rose 300 per cent between 1961 and 1975; by 1975 they represented one-third of all social assistance cases in Ontario. ${ }^{31}$ This increase was partly attributable to the liberalization of divorce laws in Canada in the late 1960s, as well as the general lack of enforcement of court-ordered child support from fathers. ${ }^{32}$ The lack of access to affordable daycare and the difficulty that women had in finding anything but precarious and part-time work meant that many single mothers turned to welfare for survival. ${ }^{33}$

Finally, the emergence of the second-wave women's movement in the late 1960s and early 1970s was a force in advancing the view that single mothers should be seen and treated as employable. One of the central objectives of the mainstream (liberal-leaning) strain of the women's movement that dominated various government bodies (such as federal and provincial status-of-women councils) as well as some non-governmental organizations was to make changes that furthered women's ability to achieve independence and autonomy and increased the recognition of women as employable and equal to men in the paid workforce. The women's movement was also instrumental in bringing attention to, and politicizing, the situation of single mothers, seeing them as a disadvantaged group owing to their having to perform as both breadwinner and parent. ${ }^{34}$ Several government reports brought attention to the plight of single mothers, including the Report of the Special Senate Committee on Poverty, its renegade counterpart, the Real Poverty Report, and the Report of the Royal Commission on the Status of Women. ${ }^{35}$ For example, the Ontario

31. Irving, No Poor Law, 30. As Margaret Little notes, in the first three years of CAP, the number of FBA recipients increased from 10,056 to 20,428, and the costs associated with this group escalated from $\$ 17$ million to $\$ 58.9$ million (only FBA was cost-shared on 50/50 basis). Little, "No Car," 141.

32. Baker \& Tippen, Poverty, 83.

33. See also Little, "No Car"; Lynne Marks, Margaret Little, Megan Gaucher \& T. R. Noddings, "'A Job That Should Be Respected': Contested Visions of Motherhood and English Canada's Second Wave Women's Movements, 1970-1990," Women's History Review 25, 5 (2016): 1-20; Baker \& Tippen, Poverty; Wendy McKeen, "Welfare Mother' Activism, Mainstream Feminism, and the Cunning of History in Ontario's 1970s Welfare Debate," Journal of Women, Politics and Policy 39, 1 (2018): 75-103.

34. For further information see Wendy McKeen, "Seen but Not Heard: The Construction of 'Welfare Mothers' in Canada's Late 1960s/Early 1970s 'War on Poverty," Canadian Woman Studies/les cahiers de la femme 29, 3 (2012): 107-123.

35. Canada, Parliament, Senate, Special Committee on Poverty, Poverty in Canada: Report of the Special Senate Committee on Poverty (Ottawa: Information Canada, 1971); Ian Adams, William Cameron, Brian Hill \& Peter Penz, The Real Poverty Report (Edmonton: M. B. Hurtig, 1971); Canada, Royal Commission on the Status of Women, Report of the Royal Commission on the Status of Women in Canada (Ottawa: Information Canada, 1970). 
government's brief to the Senate Committee on Poverty identified difficulties facing single mothers on welfare: the lack of jobs available, the fact that they had to cover the costs of both work and childcare, and the fact that they were often unable to earn more from employment than they could obtain on social assistance. ${ }^{36}$ To be clear, there were other women's voices on this issue, including the more radical grassroots women's movement - a strain of feminism that saw women's poverty as a systemic problem: the outcome of a class- and gender-biased system based on capitalism and patriarchy. ${ }^{37}$ Also, mobilized welfare mother groups that had begun organizing in the late 1960s became active in debates on welfare reform - a topic addressed further below.

\section{Ontario's Welfare Debate and the Issue of Welfare Mothers}

Following the 1975 publication of the Report of the Special Program Review (known as the Henderson Report), the Ontario government moved quickly to implement austerity, imposing severe cuts to social services in early 1976 under the guise of its "Joint Financial Restraint Program." As Irving noted, social services were increased 5.5 per cent that year, yet the cost of living was about twice that amount and overall government spending increased 10 per cent. ${ }^{38}$ The government also made changes to the tax structure in ways that shifted more of the economic burden from corporations and the rich to private individuals. ${ }^{39}$

The Ontario government began to acknowledge the issue of welfare mothers in the late 1960s and early 1970s; it commissioned a study of the problem, published in 1973, consisting of an extensive survey of FBA mothers. The dominant perspective taking hold at various levels of government at this time, including in Ontario, was that single mothers on welfare were at least potentially employable. ${ }^{40}$ Both the Hanson Report, on community and social services, and

36. Ontario Department of Social and Family Services, A Brief Prepared for the Special Senate Committee on Poverty, n.d., RG29-138-0-84, box 7, Archives of Ontario, Toronto (hereafter AO), 8 .

37. For further information, see McKeen, “'Welfare Mother' Activism."

38. Despite Ontario's unemployment rate being between 7 and 8 per cent at that time, governments and some right-wing commentators were raising the concern that too many ablebodied people on welfare were shirking work. Community and social services minister James Taylor announced that all able-bodied recipients would be required to take whatever job was available or be denied welfare. Irving, No Poor Law, 34 .

39. Between 1959/60 and 1980/81, corporate taxes went from being 25 per cent of Ontario's revenue to 11.5 per cent; personal taxes went from 15 per cent to 23 per cent of revenue; and, in 1980/81, sales taxes were 16.6 per cent. See Irving, No Poor Law, 34. According to Marvyn Novick, social spending declined significantly as a proportion of the gross provincial product (GPP): between 1976 and 1980, social spending dropped from comprising 34.3 per cent of the GPP to only 25.6 per cent. See Novick, "Social Policy," 392.

40. See, for example, Canada, Minister of National Health and Welfare, Working Paper on 
the Henderson Report endorsed this view, and following publication of the latter, the Ontario MCSs began to adopt policy that included work incentives for welfare mothers. The ministry's new policies were based on new forms of governance resting on the principle that the able-bodied needed "a hand up to self-sufficiency, not a handout." ${ }^{\text {11 }}$ Several work-incentive measures targeting welfare mothers were introduced over the 1970s and early and mid-1980s under the leadership of three consecutive male Ministers of Community and Social Services: James Taylor, who took over the MCSS in 1975, introduced the (federal-provincial) "sole-support mothers pilot project" in November 1976;42 Keith Norton, who took over in spring 1977, introduced the Work Incentive Program (W IN) in September 1979 (implemented in January 1980); ${ }^{43}$ and Frank Drea, who assumed leadership of MCSS in 1981, announced a plan to integrate sole-support mothers receiving provincial FBA benefits into the municipally run General Welfare Assistance (GWA) program (a program oriented to "employable" recipients) and, shortly thereafter, mounted the Employment Supports Initiative (ESI) - initially known by the acronym ASPIRE (Assisting Single Parents in Reaching Employment) - which ran from summer 1982 to the end of $1986 .{ }^{44}$ While these measures varied somewhat in approach and

Social Security in Canada (Ottawa: Minister of Health and Welfare, 1973). It must be stressed that the liberal belief in the "work ethic" and the focus on employability had always been a major feature of the welfare system owing to its historical roots in the Canadian poor relief system. However, it was not until the 1970s that it became a much stronger focus within welfare policy and was broadened to include single mothers - a group that had always been seen as exempt from the principle. See Little, "No Car."

41. “Wrong Tack on Benefits," editorial, Sunday Star, 21 June 1981.

42. The aim of the pilot project was to assist sole-support mothers receiving FBA, to encourage them "to return to the labour force as productive employees" on a full-time basis. Under the program, women could access such services as "assessment," available community services, training offered by the Board of Education, community colleges, and universities, and a threeweek course in "orientation to employment." Once a woman entered full-time employment, FBA benefits would be phased out and she would receive three months of coverage of health insurance, prescription drugs, and dental care. The Federal-Provincial Pilot Project for SoleSupport Mothers, 7 May 1980, Ministry of Community and Social Services (MCSS), box 140124, file 15, City of Toronto Archives (hereafter, СтA).

43. The win program provided a monthly wage supplement (of $\$ 100$ to $\$ 150$ ) for up to two years to recipients who entered full-time employment. They would also receive fringe benefits (as above), and a back-to-work grant of \$225 over three months. Ontario Ministry of Community and Social Services (COMSOC), "Norton Encourages Self-Sufficiency for Family Benefits Recipients," news release, 19 September 1979, RG29-09, accession no. 17163, box 45, AO. Erosion of benefits for the program began in 1981 and continued to the end of 1985 when the program ended. See Evans, "Work Incentives," 130.

44. ASPIRE/ESI consisted of an assessment of the barriers to labour-force participation facing each individual, pre-employment services such as life-skills and job-search counselling, and information and referral to education and training programs. Participants could also be partially reimbursed for such employment-related expenses as transportation, supplies, and childcare. See Evans, "Work Incentives," 131. 
detail, they offered similar packages of incentives intended to encourage single mothers to leave welfare for full-time paid employment. The incentives included small financial supplements to income that were phased out over a period once a person entered employment; small one-time payments to cover "back to work" expenses or to reimburse employment-related expenses; and continued entitlement to coverage for health insurance, prescription drugs, and dental services for a period after leaving welfare. The programs also generally granted recipients access to supportive services such as assessment, education and training, and life skills and job-search counselling.

The government's imposition of financial restraints on social spending (along with, as mentioned previously, the growing presence of right-wing commentary) made for an intense period of social policy debate, with the progressive social policy sector seeking to challenge what it perceived to be a cruel attack on the most vulnerable in society, with the claim that "Ontario has conducted its program of restraint on the backs of the needy and dependent in the province." ${ }^{45}$ In Toronto this sector consisted of a few high-profile, largely leftliberal, middle-class social policy organizations, including the Social Planning Council of Metropolitan Toronto (SРсмт) and Ontario Welfare Council (owc); social service advocacy coalitions, such as Metro Agencies Action for Change (MAAC); social welfare agencies that worked directly with welfare clients, such as Opportunity for Advancement (OFA) and Times Change (TC); and women's organizations, particularly the Ontario Status of Women Council (OSWC) and, more distantly, the National Action Committee on the Status of Women (NAC). ${ }^{46}$ These organizations worked to document and publicize the punitive effects of government restraints on social welfare, especially the declining value of welfare benefits, increasing poverty, and the deficiencies of such programs as WIN. ${ }^{47}$ With benefits at well below subsistence levels, and

\section{Novick, "Social Policy," 395.}

46. MAAC was a coalition composed of representatives of established social service agencies in Toronto involved in delivering direct social services and active in social policy debate through the 1970s, including on the issue of welfare mothers. See Gloria Pearl \& Douglas H. Barr, "Agencies Advocating Together," Social Casework (December 1976): 611-618. Opportunities for Advancement and Times Change were Toronto-based self-help agencies that delivered services to welfare mothers. The Ontario Status of Women Council was a government agency concerned with furthering the status of women. The National Action Committee on the Status of Women was a national umbrella advocacy group of women's organizations that was partially funded by the federal government. For more on the relationship of the mainstream women's movement with welfare mother groups, see McKeen, "'Welfare Mother' Activism."

47. Between 1975 and 1982 the purchasing power of benefits eroded 30 per cent under GWA and about 25 per cent under the FBA program. See Social Planning Council of Metropolitan Toronto, Social Infopac 1, 3 (1983). On the win program, see Ontario Welfare Council (owC), Settling for Less: A Response to the Work Incentive Program by the Ontario Welfare Council, October 1979, F837, box 3, AO. On social assistance benefits, see Social Planning Council of Metropolitan Toronto (SPCM) \& Ontario Social Development Council (OSDC),... And the Poor Get Poorer: A Study of Social Welfare Programs in Ontario (Toronto, September 1983). 
inflation rising, these groups persistently called for social assistance benefits to be increased and be indexed to inflation, while also urging more job creation and greater access to services such as daycare and skills training. To be clear, these efforts were also largely supported by the broader progressive community in Ontario that also included unions, faith-based groups, church leaders, and the provincial NDP as well as individual MPPS within the party.

Social policy and women's organizations, along with their allies, were also concerned with the situation of single mothers on welfare. These groups favoured restitution for welfare mothers and supported many of the positions and demands advanced by welfare mothers' groups, particularly the call for increased benefits and more flexibility in allowing mothers to supplement their benefits through earnings. While progressive social policy organizations largely supported the idea of seeing single mothers as potentially employable and deserving of social supports to assist them in achieving their goals, they were critical of the government for failing to take seriously the employment barriers that welfare mothers faced. Activists were also critical of the government for not providing sufficient support services, such as childcare, job training, and educational opportunities, to enable single mothers to leave welfare for paid work. They also opposed any measures that would force women involuntarily into paid work. ${ }^{48}$ Indeed, within the context of the recession, high unemployment, and the tightening of eligibility for welfare, some within this sector viewed the government's sudden interest in pushing single mothers into the workforce as an attack on welfare mothers - a cynical ploy to reduce social spending, scapegoat welfare mothers, and recast them as unworthy of welfare. As owC president John Barnes expressed in a speech at the council's annual meeting in 1976, "The helpless victims of social change become in some minds the causes of the crisis that has been created in the health and social services. I did not believe that we would ever import the disgraceful American practice of making the single mother of small dependent children the enemy of the state. Yet, we appear to be coming to that pass in 1976." ${ }^{19}$

Further to the margins within the progressive social policy community were several welfare mothers' groups that were active at this time. Welfare mothers first began mobilizing in the late 1960s just as social justice and equality were becoming public concerns. While many of these women had been part of the antipoverty groups that emerged in the late 1960s, they later formed their own organizations. They came together out of a shared sense that they had rights as citizens - that welfare was a right rather than a charity and that they had a right to live on par with other families. ${ }^{50}$

48. owC, Settling for Less; SPCMT \& OSDC, And the Poor Get Poorer.

49. John Barnes, "Report of the President of the Ontario Welfare Council to the Annual Meeting, May 6, 1976, Toronto," 6 May 1976, Ontario Welfare Council Papers, F837, box 65, AO.

50. For more discussion of welfare mother groups see, McKeen, "Seen But Not Heard"; 
Single mothers experienced significant hardship and frustration under the welfare system. Welfare benefit levels were not adequate to their needs and were not keeping pace with inflation: in 1961, families on FBA received 35.5 per cent of the average family income; by 1971 they received 29 per cent, and ten years later the figure was 25 per cent. ${ }^{51}$ The rising cost of housing and food meant that these families had trouble covering their basic needs. They had little access to jobs that paid enough, and penalizing recoupment rates and rules that set low ceilings on employment earnings seriously limited their ability to supplement their benefits with employment earnings. Services that were needed to make paid employment a viable option, such as childcare and training and upgrading programs, were severely lacking. Many welfare mothers resented the lack of transparency in the system, the discretionary power that welfare workers and bureaucrats had, and the often humiliating and patronizing treatment they experienced at the hands of officials. Many felt the system undermined their dignity and their ability to mother and to participate in their community.

A number of welfare mothers' groups that formed in Toronto in the 1970s and 1980s became active in social welfare debates, including Operation Family Rights (1972-73), Coalition for the Right to Earn (1974-unknown), the Mother-Led Union (1974-76), Women's Action Group (1974-76), Women After Rights (1976), Family Benefits Work Group (1978-83), Mothers' Action Group (1982-unknown), and Sole Support Parents Coalition (1982-85).52 These grassroots groups varied in size and membership; they were generally made up of welfare mothers but sometimes included representatives of human service agencies or professionals. They held membership meetings, developed critiques, formulated demands, and generally sought to raise awareness and to influence policymakers through such activities as holding demonstrations and conferences and publishing newsletters, newspaper articles, press releases, and briefs. Organizations such as the Mother-Led Union (MLU), Family Benefits Work Group (FBWG), and Mothers' Action Group (MAG) were fairly successful in gaining credibility and capturing public attention (i.e. their activities and positions were often covered in the press). In general, the key demands of these groups were for improvements to the adequacy of welfare benefits, changes to the recoupment rate and ceilings on allowable earnings, an increased ability to supplement benefits with part-time earnings, greater provision of childcare services, and more access to job and skills training and education. ${ }^{53}$

McKeen, "Welfare Mother' Activism."

51. Little, "No Car," 144.

52. The membership of these groups tended to be homogenous (i.e. white), in part reflecting the fact that many immigrant women, racialized women, and Indigenous women had difficulty accessing welfare benefits, and in part because their voices were generally suppressed because of racism and/or they identified more strongly with struggles combatting racism.

53. Coalition for the Right to Earn, What Is the Real Story behind Family Benefits Allowances 
More radical ideas were also expressed, however. The MLU, for example, which was active between 1973 and 1976, had several locals in Toronto. ${ }^{54}$ This group took the position that sole-support mothers on welfare were entitled to support simply on the basis that they were already working and contributing to society through their work of raising the next generation of citizens. ${ }^{55}$ In 1976, the MLU's demands were for equal pay with foster mothers, a higher earning capacity for mothers on FBA benefits, and free 24-hour childcare for all women, whether working inside or outside of the home. ${ }^{56}$ At one point the group threatened to go on strike by way of having mothers drop their children off on the steps of Queen's Park. This plan was ultimately abandoned, however, largely because many mothers feared that the government could retaliate by taking their children from them on the grounds of negligence and/or by taking away their benefits. The FBWG and the MAG - two of the more visible groups in the late 1970 s and early 1980 s - while slightly more liberal in orientation, also firmly believed that society had a fundamental responsibility to support welfare mothers and their children..$^{57}$

The Ontario government's emphasis on introducing work incentives for welfare mothers gave rise to considerable consternation, fear, and anger across the population of welfare mothers. Groups such as the MLU did not agree that paid work was the easy answer for welfare mothers given the limited range and quality of jobs available to women and the inadequacy of childcare services, job training, and other supportive services. The MLU also saw this approach as failing to recognize that single mothers were already working and contributing to society through raising children. Most of all, they believed that mothers

(Mother's Allowance) Allowable Earnings?, August 1974, Social Planning Council, box 139800, file 36, Sole Support Parents, CTA.

54. See, for example, Margaret Daly, "A Man Away from Poverty: The Disadvantaged Woman," in Sheila Arnopoulos, S. Brown, Diane Cohen, Margaret Daly \& Kathryn Govier, eds., To See Ourselves: Five Views on Canadian Women (Ottawa: Information Canada, 1975), 103-123; June Menzies, "New Positions for Public Policy: A Position Paper on the One Parent Family," Canadian Advisory Council on the Status of Women, Ottawa, April 1976. For additional description of the welfare mother groups, see McKeen, "Welfare Mother' Activism”; Little \& Marks, "Ontario and British Columbia."

55. Brief on Financial Independence for Single Support Mothers, Mother Led Union, 6 May 1974, Ontario Status of Women Council (hereafter OsWC), RG69-5, box 1, AO.

56. MLU, [no title], 3 March 1976, fonds 220, series 100, box 46662, file 950, folio 3, Mothers Allowance and Dependent Fathers, 1963-76, Community Services Department, Correspondence, Subject Files of the Commissioner, 1931-81, СтA.

57. The FBWG (1978-83), composed of both welfare mothers and social policy and community service organizations, was funded at times by the federal department of Secretary of State, Children's Aid Society, and Metro Toronto. The M AG emerged in 1982 and comprised welfare mothers united in their fight for educational incentives, affordable housing, and a humanitarian welfare system. Mothers' Action Group (M AG), Protecting Our Own, April 1982, Canadian Women's Movement Archives (CWMA), University of Ottawa; Family Benefits Work Group (FBWG), Women and Children on Welfare: A Poverty Trap, 15 May 1975, fonds 76, СтA. 
should have the right to autonomy in making decisions about whether and when to enter paid employment and did not believe that this power should be in the hands of government bureaucrats and officials who were so removed from the realities of these women's lives. As one MLU spokesperson put it, in response to MCSS Minister Taylor's 1976 announcement of the sole-support mothers pilot project,

Women who wish to go back to work should be given every assistance in this effort. ... But this is not the sort of assistance the Ministry has in mind. ... [T] be ours but will depend on the assessment of us made by welfare offices. ... [I]t would have us become the source of cheap labor for business and industry, and force us to compete with the working poor ... and he [Taylor] tries to rationalize these measures in the name of equality for women. ${ }^{58}$

In its 1982 brief Protecting Our Own, the M AG claimed that the family benefits system was a "miserable failure," that the government had "never made any serious effort to ensure the proper support services for sole-support parents, despite claims to the contrary," and that its policies were "politically abusing" welfare mothers and had produced only "anxiety, distrust, anger and fear" in them. ${ }^{59}$

Given what we know now about the impacts of these programs, the criticisms expressed by the progressive sector, including welfare mothers, appear to have been valid and prescient. The research in this area suggests that these so-called work-incentive measures had very little impact, and few women benefitted from them. The limited nature of the financial incentives and the failure of the government to follow through with providing the needed daycare and other support services meant that few women could make use of the programs. For the most part, benefits under these programs were restricted to those entering full-time employment (as opposed to part-time) and this was not a viable option for many women with children. According to Evans, the WIN program failed to increase full-time work among FBA recipients and at no time did participation in the program exceed 3 per cent of sole-support mothers on welfare. ${ }^{60}$ The ASPIRE/ESI program also failed to increase employment opportunities for these mothers. Margaret Little cites studies showing that only 10 per cent of eligible recipients ever participated in the services available under the ESI program. ${ }^{61}$ Evans concludes that the greatest impact of the program was to make it appear that the Ontario government was "doing something about welfare dependency and the cost of social assistance."62

58. Special Bulletin to Members and Supporters by the Mother-Led Union, 14 March 1976, Mother Led Union file, CWMA.

59. MAG, Protecting Our Own.

60. Evans, "Work Incentives," 129.

61. Little, "No Car," 161.

62. Evans, "Work Incentives," 132. 
The question to which this article now turns is this: How? Given the resistance to, and criticism of, the government's attempt to reorient welfare for single mothers around work incentives, how did situated government actors manage to secure sufficient legitimacy to allow them to continue pursuing this approach? How did they engage with their critics and those who would resist these initiatives? Finally, to what extent did the actions of some social policy/ social service actors inadvertently align with the government's agenda? An important part of the answer to these questions lies in understanding the ways that situated government actors were able to control and shape the debate on welfare mothers. One of the initial ways this was done was by authorizing expert knowledge on the population of welfare mothers in an attempt to define the needs of this group. The next section focuses on this question by examining a 1973 report, Family Benefits Mothers in Metropolitan Toronto, which was the only major study on welfare mothers sponsored and published by the Ontario government.

\section{Constructing Welfare Mothers' Needs}

The RePort FAMILY BeNEFITS Mothers in Metropolitan Toronto was an early effort by the government to set the terms of the debate on welfare mothers. The study was intended to provide the government with a resource for policymaking in this area and, as the only major government study on this topic, it cast a long shadow, with occasional reference to it being made over the decade by officials and bureaucrats, including those responsible for developing work-incentive measures. ${ }^{63}$ The research, carried out by the MCss's Research and Planning Branch and written by Jean James, was based on a survey of 414 mothers receiving FBA in Metropolitan Toronto. ${ }^{64}$ What is striking is that while the study purported to be a scientific account of lone mothers on welfare, it clearly cast welfare mothers as deficient individuals who were to blame for their own predicament.

As Alice O'Connor describes in her study of US poverty discourse in the 20th century, poverty was narrowly defined in the mid-1970s as a set of issues revolving around the characteristics, behaviour, and attitudes of poor people and the programs and benefits they received. ${ }^{65}$ The "scientific" studies on poverty at that time assumed and upheld conservative and middle-class

63. For example, data from this report was still being used in 1978 when the win program was being developed. See Doris Guyatt, Policy Secretariat, MCss, "Memo on Sole Support Mothers," 16 May 1978; John Nywening, Secretariat for Social Development, "Memo on the FBA Program," to Deputy Provincial Secretary, 27 November 1978, both in RG54-3, box ww2, Provincial Secretary for Social Development, Policy development files, AO.

64. Jean James, Family Benefits Mothers in Metropolitan Toronto (Toronto: Ontario Ministry of Community and Social Services, 1973).

65. O'Connor, Poverty Knowledge. 
notions that to be on welfare was to be a failure. This was the "culture of poverty" understanding, whereby certain characteristics predispose people to becoming welfare recipients. ${ }^{66}$ This was precisely the kind of knowledge that was reproduced by the James Report. The Ontario study largely focused on documenting the characteristics, attitudes, and behaviour of welfare recipients. For example, primary interests were on discovering possible predisposing factors toward single parenthood and the "current dependency" (e.g. fertility history, education level, age at marriage, family background) of those mothers, and determining whether the welfare system itself contributed to perpetuating poverty from one generation to another. Another focus was on exploring recipients' attitudes toward "being dependent on the public purse," whether they felt stigmatized when applying for welfare, what they would do differently if they had their life to live over again, and whether they were as critical of the welfare system as "other segments of society" that viewed it as intrusive and demeaning. ${ }^{67}$ The study also considered the "labour force behavior" of recipients and how this was affected by various personal variables and recipients' attitudes toward paid employment.

The biases of this report are even more evident when compared to the discourse found in another Ontario report on poverty and welfare that had been published a year earlier, namely, the Report of the Task Force on Employment Opportunities for Welfare Recipients. The latter task force was appointed in October 1971 by the Minister of Social and Family Services (as it was called then) and was chaired by lawyer Barry Swadron. ${ }^{68}$ The impetus for the Swadron task force was similar to that driving the James study: concerns about the rising numbers of welfare recipients, the rising costs of welfare, and the question of what conditions should be put in place regarding the requirement of recipients to seek paid employment. A key difference is that while the James Report was concerned with single mothers on welfare under the FBA program, the Swadron Report was concerned with the General Welfare Assistance program, whose recipients were primarily men. Unlike women, male GWA recipients were generally assumed to be workers and/or the breadwinners of the family and, under GWA, were required to make reasonable efforts to secure employment for which they were capable. There was some anxiety at the time,

66. O'Connor, Poverty Knowledge, 239. A "culture of poverty" perspective emphasizes moralist/behavioural explanations of poverty as opposed to structural understandings that identify inequitable social structures. The former constructed poverty, and being in receipt of welfare, as signs of deficiency and "dependency" and as a syndrome, cycle, or lifestyle in which individuals were caught.

67. James, Family Benefits, 202, 30.

68. Barry B. Swadron, Task Force on Employment Opportunities for Welfare Recipients: A Report to the Honourable René Brunelle, Ontario Minister of Social and Family Services (Toronto: Government of Ontario, 1972). As far as I have been able to determine, the James Report and the Swadron Report were the only research reports sponsored and published by the Ontario government on welfare and employability in the 1970s. 
however, that growing numbers of single men, especially young men, were choosing welfare over paid employment - described by the minister responsible at the time, Thomas Wells, as a problem of "freeloaders and loafers." ${ }^{69}$

The attitude expressed in the Swadron Report, however, clearly contrasted to that of the James Report. While both reports assumed the economistic/ male-breadwinner model as foundational, the authors of the Swadron Report were much less concerned with the behaviour of the poor and more willing to acknowledge the messiness of the social world. Relative to the James Report, the Swadron Report showed empathy for the situation of hard-to-place single men and promoted a message of equality and inclusion. It advanced the view that governments should be responsible for ensuring that all recipients be treated with dignity and no one left behind. Its recommendations aligned with what Peck and others have termed a "human capital development" approach, in contrast to a "work first" approach - while the latter aims to help the worst off, the former tends to skim off the best candidates for benefits and leaves little for the rest. ${ }^{70}$

As O'Connor observed regarding US poverty research, the problem was "what was being left out" - or, as Fraser might ask, what was lost in translating politicized needs (e.g. the right of single mothers to welfare) into administrative needs? ${ }^{71}$ Indeed, the James Report clearly performed the work of what Fraser describes as decontextualization and recontextualization. The text leaves out the messy social world and political context in which poor single mothers live out their everyday lives, including the kind of oppression, inequality, and regulation that they regularly face. It screens out recognition of the work of caring for dependents and the complexities and difficulties of doing this while living in poverty and often confronting other challenges, such as being a lone parent, facing racist or anti-immigrant attitudes and discrimination, dealing with their own illness and disability or that of a child or other dependent family member for whom they care, and/or facing such conditions as precarious paid work, precarious housing, and lack of childcare and other social supports, among many others. The James Report on FBA mothers ultimately presented the needs of welfare mothers only within the terms of the dominant, economistic, and patriarchal ideology and structures, which privileges male-centred notions of employment and renders women's care work invisible and of little value.

This analysis also aligns with Schram's insights concerning the dominance of ETM discourse in contemporary welfare policy research. The James Report simply reinforced the belief that welfare mothers are "the other" - an

69. Minister of Social and Family Services, "Thomas L. Wells, Minister of Social and Family Services, on the Establishment of a Task Force on Employment Opportunities for Welfare Recipients," press release, 24 October 1971, fonds 220, series 100, box 46703, file 1342, CтA.

70. Peck, Workfare States, 90.

71. O'Connor, Poverty Knowledge, 240; Fraser, "Struggle over Needs." 
underclass, dependents, and public burdens - and that the only solution lies in their management and rehabilitation. This, then, was the kind of limited expert knowledge that became an essential part of the repertoire from which Ontario officials drew in designing and rationalizing the work-incentive programs for welfare mothers that were to come.

\section{Work Incentives for Welfare Mothers as the New Normal}

\section{Practices of Assemblage}

Tania Li's conceptualization of generic practices of assemblage provides a useful framework for deciphering the politics at play in Ontario's debate on work incentives for welfare mothers in the 1970s and early 1980s. In many ways this policy direction was not inevitable; it was the outcome of work done by specific individuals within the government (and, to a lesser extent, outside government) to build and secure a particular assemblage, or, to use Fraser's term, expert-needs discourse. While the discourse of the James Report, as well as others imported from the United States and elsewhere, formed part of the ideational foundations upon which (mainly) key government officials drew in the 1970s, a close examination of the narratives of these actors shows that it also involved the work of forging alignments and managing failures and contradictions, as well as the relative willingness of many progressive actors and organizations to contain their critique.

For example, with respect to the practice of forging alignments, a key government tactic was to present work incentives for welfare mothers in ways that aligned with the vocabulary of progressive actors (including social policy and social service organizations, feminists, and welfare mother groups). Indeed, government actors adopted many of the progressive claims of these groups. For example, when Minister Taylor launched a media campaign in March 1976 for his plan to introduce legislation that aimed to push welfare mothers into employment, he framed it in terms of women's liberation - as helping them to achieve financial independence and break from the tradition of dependency: "I think you'll find we just want to encourage women to do something meaningful in society, rather than just sit home alone, while their children are at school." ${ }^{2}$ Minister Norton presented the wiN program as a "breaking away from the traditional maintenance environment which, for many social assistance recipients, may prove to be more of a quicksand than a road to better things." ${ }^{73}$ Minister Frank Drea justified his plan to integrate FBA and GWA and put greater focus on work incentives for single mothers on welfare with the claim that the welfare system was a "trap" that isolated recipients from the

73. сомsoc, "Norton Encourages Self-Sufficiency." 
social and economic mainstream of society, did not reflect the new reality of women's greater participation in the paid workforce, and "robbed recipients of the self-confidence to obtain employment or training." 74 He also described this plan as being a "moral obligation" of government to "able-bodied recipients." 75

Another way that the MCSS attempted to appeal to progressives was to emphasize the importance of providing social and employment supports. Officials repeatedly claimed that participants in work-incentive programs would be provided with an array of options in this regard. For example, with respect to the sole-support mothers pilot project, Taylor announced that "services would be tailored to meet their individual needs and goals and [there would be] a wide variety of training options." ${ }^{76}$ Referring to the w IN project in June 1980, Norton declared that "a wide range of self-help or employmentrelated services" would be available to choose from. ${ }^{77} \mathrm{He}$ also emphasized that in taking this approach Ontario was choosing not to follow the approach taken by Alberta, in which work requirements were a mandatory condition for receiving social assistance for certain welfare mothers. ${ }^{78}$

The language of government officials also carefully harmonized with the humanistic and therapeutic discourse of the social service agencies and helping professions involved in welfare debates. Officials repeatedly took the position that many sole-support mothers were not "ready" to enter full-time employment because of low self-esteem, that they needed help in making the necessary "adjustments" in family life, and that the program would set them up to achieve their goals and succeed in "transitioning" into paid employment. ${ }^{79}$ Government actors spoke of the way programs catered to the unique needs of sole-support parents; they were said to be about helping and empowering women, building their self-confidence, encouraging them to strive toward "independence." 80 These ideas were often reflected in the acronyms for these programs (e.g. WIN, ASPIRE).

74. MCss, Report on Selected Income Assistance Initiatives, 21 April 1982, Community Services Division Policy Files 1984-86, RG29-169, AO.

75. "Remarks by Drea to Annual Convention of the Ontario Municipal Social Services Association," 1 June 1981, RG69-4, box 30, AO.

76. MCss, "Project to Help Sole Support Mothers Obtain Employment," press release, 30 November 1976, RG29-08, accession no. 17161, box 49, AO.

77. "Minister Norton's Address to the Ontario Municipal Social Services Association," 2 June 1980, RG29-09, transfer no. 85-66, box 6, AO.

78. "Minister Norton's Address."

79. MCss, The Federal-Provincial Pilot Project for Sole-Support Mothers, 7 May 1980, MCss, box 140124, file 15, СтA.

80. For example, Norton commented as follows on the win program: "I recognize the difficulties involved in the transition from social assistance to independence. Indeed, some recipients may attempt this transition several times before they are ultimately successful in maintaining full-time employment. ... [W] e must focus upon initiatives that encourage 
Secondly, government officials put considerable energy into managing failures and contradictions in relation to the measures that were implemented. As we saw earlier, oppositional groups often saw work-incentive programs as being narrowly focused and not helpful to the majority of welfare mothers. While the programs were almost solely oriented toward encouraging full-time employment, this was not a viable option for most welfare mothers because of a lack of education and skill-training opportunities and childcare options. Indeed, not only did the programs implemented not seem to reflect what was already known about the support-service needs of welfare mothers and their barriers to employment, but they also ignored the critically high rate of unemployment and the fact that many recipients were not equipped to compete for the few job openings. The programs did nothing to address job creation, job training, job upgrading, and the provision of support services. They continued to create serious disincentives to part-time work, meaning that many welfare mothers were left having to rely on inadequate benefits. Moreover, as previously mentioned, some welfare mother groups claimed that women were already doing meaningful work by raising their children and had a right to welfare on these grounds alone, and these groups were opposed to government officials and bureaucrats having the right to make decisions about the "employability" of individual mothers. The MAG argued, for example, that these decisions were subjective and arbitrarily imposed by bureaucrats without taking account of the needs of children or a family's ability to cope, that the decision "should not and cannot be left to bureaucrats whose decisions are directly affected by budget considerations," and that each individual woman should have the right to decide whether and when to enter paid employment. ${ }^{81}$

While government actors claimed to welcome debate on these issues, they went to great lengths to smooth over and close down critical scrutiny by progressive actors. Li describes this activity in terms of "absorbing critique within the realm of expertise," "managing dialogue," and "presenting failure as the outcome of rectifiable deficiencies." ${ }^{82}$ For example, we see attempts by ministry officials to absorb critique in the following exchange between MAAC president Gloria Pearl and MCss minister Keith Norton over the pilot project for solesupport mothers. Pearl commented that this project did "not address itself to the rehabilitative needs of the majority of mothers on FB"; Norton replied that there was no existing knowledge about the needs of welfare mothers and invited MAAC to undertake to define those needs, to which Pearl expressed concern that Norton had "somehow overlooked the main thrust of [her] letter," noting that she was "surprised with [his] request ... to define the rehabilitative

and reward self-sufficiency. In effect, we need to ... provide incentives to help people to help themselves." See Ontario, Legislative Assembly, Hansard, 31st Parl, 4th Sess (19 June 1980) at 3065.

81. MAG, Protecting Our Own, 8, 9.

82. Li, "Practices of Assemblage." 
needs of the large group of sole support mothers." ${ }^{83}$ She wrote, "In our opinion that data is available and has been available for some time through the office of the Focus on Change Program run by the YwCA of Metro Toronto" - and also noted the inadequacy of government support to the latter program. ${ }^{84}$

In addition, government officials often dismissed the concern that programs were designed in ways that benefitted only a small minority of women. For example, in the case of the pilot project for sole-support mothers, Norton argued that those who could not benefit from the program could seek financial support through the supplementation program for working poor families in Toronto; however, the latter program was one that was also being criticized at the time for being very limited and benefitting very few. The minister also attempted to justify low welfare rates by claiming that welfare recipients were compensated by increases in other programs, such as child benefits. ${ }^{85}$ MCSS ministers and other officials often claimed that incentives for parttime employment were not needed and that, in any case, such work would not make women economically independent and was therefore not an appropriate program goal. ${ }^{86}$ Government actors also often attempted to lower public expectations of what governments could achieve, frequently referencing "financial constraints." With regard to the pilot project, for example, Norton claimed that while those with low income had priority for subsidized day care spaces, the government could not guarantee spaces for anyone seeking and securing employment. While he accepted that many recipients required academic upgrading and possibly skills training in order to secure a job that paid enough to make it worthwhile, he emphasized that "the project does not encourage education for its own sake" but is only as a means to employment, and that "the women are counselled" regarding the need to earn enough to

83. Gloria Pearl to Keith Norton, 18 April 1977; Norton to Pearl, 9 May 1977; Pearl to Norton, n.d., all in SC 40, box 174, file 15 , CTA.

84. Pearl to Norton, n.d.

85. For example, as Norton wrote in a reply to a citizen, Leslie Hahn, who was concerned about the inadequacy of the FBA rate increase, "Although the 10 per cent increase in these rates on April 11980 may not appear to compensate for the 12.5 per cent inflation rate since the previous Family Benefits rate increase in January 1979, families with children actually received an overall increase of approximately 12 per cent due to increases in federal child based transfers." Norton to Hahn, 4 July 1980, sc 40, box 175, file 28, c тA.

86. For example, as Norton commented in a letter to the chair of MAAC, "Many family benefits recipients take advantage of the provisions which allow them to work part-time. It does not appear that an employment orientation course is required to encourage recipients to do this. In addition part-time work is unlikely to make a recipient economically independent. In this sense, then, it would not relate to the goal of our project." See Norton to Pearl, 9 May 1977. In another policy document, the ability of single mothers on welfare to earn on a part-time basis was presented as a disincentive to entering full-time employment and, therefore, as a barrier to the government's policy of incentivizing full-time employment. See comsoc, Work Incentives for Recipients of Long-Term Social Assistance, Strategic Planning and Policy Secretariat Report, 1 June 1979, RG-29-09, 17163, Box 45, AO. 
cover their costs and achieve a better standard of living. ${ }^{87}$ As one assistant deputy minister also put it, in responding to a December 1979 letter from MAAC criticizing the WIN program, "I do not believe that government can be expected to eliminate all the difficulties which stand in the way of social assistance recipients." ${ }^{88}$ Drea also sometimes discouraged expectations about what government could achieve. For example, with regard to conquering poverty, he stated, "I don't think there has ever been a society that has penetrated the poverty line on social assistance. You'd have a real problem - if you get everybody above the poverty line, you'd draw a new poverty line because you're looking at life style." ${ }^{89}$ With respect to the call by oppositional groups to set social assistance rates to inflation, Drea replied, "I do not think there is ever going to be a time ... when social assistance payments of any description will really keep pace with inflation." 90

Officials also frequently attempted to present failure as the outcome of rectifiable deficiencies by repeatedly framing programs as works in progress. ${ }^{91}$ For example, Norton described the wiN program as "an initial step along the path of providing incentives to people to realize their expectation of life" and stated that "we came a long way ... but there is still much to do." ${ }^{92}$ Elsewhere he wrote that "we hope to take further steps in the future as the opportunities may arise within the restrictions of the finances available." ${ }^{93}$

Drea's early-1980s plan to "integrate" the provincial fBA program with the municipally run GWA program (and thereby transfer sole-support mothers into the municipally run program) caused great concern among progressive groups and welfare mothers, who feared that municipal officials and politicians would put undue pressure on some mothers to take jobs regardless of childcare availability ${ }^{94}$ Drea attempted to counter such concerns, claiming that he had never seen workers and officials at the municipal level treat clients any differently than at the provincial level, that the plan was a step toward "improving" services for welfare mothers, that municipal governments had greater expertise in the delivery of employment services, that municipalities were "innovative and imaginative" in the things they were doing in this area,

87. Norton to Pearl, 9 May 1977.

88. John Anderson to MAAC, MCSS, 19 December 1979, box 139800, file 23, CTA.

89. McNenly, "Ontario Lags on Welfare."

90. Ontario, Legislative Assembly, Hansard, 32nd Parl, 2nd Sess, Vol 3 (10 May 1982), Social Development Committee.

91. Li, "Practices of Assemblage," 265.

92. "Minister Norton's Address."

93. Anderson to MAAC, 19 December 1979.

94. "Wrong Tack on Benefits." 
and that the government was simply recognizing the "maturity of local government to deal with local needs." 95

Government officials also frequently claimed that work-incentive programs were a success and were giving welfare mothers what they wanted. Six months after implementing wiN, Norton declared that he was "cautiously ecstatic" with the program and that "there are many recipients who want to be independent and to contribute more to community life." 96 Drea declared that the ASPIRE program was a "big winner in spite of the fact there are people who told us it wouldn't work." ${ }^{97} \mathrm{He}$ also stated that "our clients prefer employment to social assistance," "they don't want to be on the dole," and "the work ethic is alive and well and prospering in Ontario." 98 Finally, government officials had very little response to claims by welfare mothers that by raising their children they were already doing meaningful work. The most that government actors offered was a blanket reassurance that no welfare mother would be forced into employment against her will (discussed further below).

Li's concept of contained critique is also an important tool for unpacking the debate in that it puts a focus on the activities of the progressive social policy sector. Indeed, while many of the "oppositional" groups involved in the debate voiced serious criticisms of the work-incentive measures, they also repeatedly claimed that they fully supported the principle of work incentives for this group. For example, the FBWG declared that the WIN program was "a small step in the right direction"; the oswC called it "an important and positive step," one with good intentions in recognizing "women's right to work if they so choose"; and the owC called the win program "a modest but welcome step forward," especially as compared to the work-for-welfare approach. ${ }^{99}$ Gloria Pearl, chairperson of MAAC, expressed to Norton that her organization was "not questioning the worth of the [federal-provincial pilot] project on sole-support mothers per se but rather its value" for the "vast majority of FBA recipients." 100 Indeed, MAAC "welcomed" and "applauded" the w IN program and committed to "monitoring the program and reviewing results

95. MCSs, Report on Selected; "Remarks by Drea”; Frank Drea, "Present Programs Costly, Drea Says," letter to the editor, Toronto Star, 4 July 1981, B3.

96. "Minister Norton's Address"; COMSOC, "Norton Encourages Self-Sufficiency."

97. MCSS, news release, 22 May 1984, Ontario Advisory Council on Women's Issues, RG69-4, box 30w D, AO.

98. MCss, news release; “Welfare Group Lying About Job Plan: Drea,” Toronto Star, 18 May 1983.

99. oswC, Comments on the Work Incentive Program for Family Benefits Recipients Announced by Ministry of Community and Social Services (Toronto: oswC, 1979), 1; owC, Settling for Less, 2 .

100. Pearl to Norton, 18 April 1977. 
as the program proceeds." ${ }^{101}$ In effect, these organizations did not want their critique to unravel the entire assemblage or expert discourse; given the choice between work incentives and no work incentives, they chose work incentives. They sought to fine-tune and adjust the model rather than propose a radically different approach (and the government clearly valued these positive responses). ${ }^{102}$

In many ways, then, these organizations willingly contributed to, and upheld, the Етм paradigm that blamed poverty and welfare dependency on the individual and saw recipients as passive objects in need of reform. ${ }^{103}$ One clear example of this is a series of five booklets, or "kit," entitled Facts for Advocacy, issued in the early 1980s by a core group within MAAC and designed to guide community groups in advocating for support services for women on social assistance. ${ }^{104}$ The content of this material is steeped in the assumption that becoming employed is the only real solution for sole-support mothers and marks a move "from economic dependence to independence." According to the booklets, this happens by way of the individual moving through a developmental process that helps them overcome their own sense of powerlessness. The stages this entails are as follows: "being isolated at home and feeling dissatisfied but unsure of what to do; making contact with a worker and/or group of women of similar status and in an environment allowing exploration of options for the future; joining a more structured group ... to participate in a program combining confidence-building, access to information and referral services, and possibly life skills training, educational upgrading, and finally, becoming more employment-focussed [sic] through enrolling in an upgrading program, entering a job training program, or obtaining part- or full-time paid employment." 105 Women were seen as experiencing barriers to independence such as lack of day care, lack of housing and adequate income, low self-esteem, and health problems - but these are treated as personal "stressors" that individuals must overcome. These booklets also emphasize self-esteem-building programs for welfare mothers, such as the ones provided by OFA. ${ }^{106}$

The problem with this kind of narrative, as Barbara Cruikshank argues, is that it legitimizes a narrow conceptualization of poverty as something that can be addressed by getting the poor to enlist themselves in their own

101. Florence Morson to Keith Norton, 22 November 1979, box 139800 (box 175), file 23, Social Allowances in Ontario, Correspondence 1975-80, стA.

102. Anderson to MAAC, 19 December 1979.

103. Fraser, "Struggle over Needs," 212.

104. Facts for Advocacy, n.d. [likely 1981], fond 76, Times Change, series 305, box 167079, file 21, item 47, ста.

105. Facts for Advocacy, iv.

106. Facts for Advocacy. 
empowerment, plan their own welfare, and meet their own needs. ${ }^{107}$ Poverty and welfare dependency are cast as results of a sense of powerlessness or lack of self-esteem rather than objectively rooted in material or social causes such as low wages, high unemployment, a lack of childcare services, and discrimination. In other words, this discourse re-poses political questions as matters of technique and, as such, is a form of anti-politics that redirects progressive interests away from tackling the more fundamental issues relating to class, gender, and race inequalities. It confines "advocacy" for welfare mothers to addressing a specific, limited range of social service issues but without reference to the larger structures of inequality in society. It assumes that inequality is inevitable and that the role of the progressive advocate is to help welfare mothers cope with their day-to-day realities. Such discourses (which, to be clear, were also embraced to some degree by the OsWC, OWC, and FBWG) served to justify the work-incentive programs, privilege full-time over parttime employment, and emphasize counselling, employment "planning," "orientation," and "self-esteem" over concrete employment training, access to educational upgrading, job creation, and daycare provision.

\section{Authoritarian Rule: Government Officials Throw Their Weight Around}

While I have argued that assemblage practices (meaning construction) were critical in allowing government officials to shape and limit the debate on work incentives for welfare mothers, this story would not be complete without a return to a broader political economy focus - specifically, the issue of power relations between the actors involved in this debate. Ontario's approach to advancing its preferred ideals and policy agenda rested on the willingness of state officials to use their greater power and authority as a means for containing and subduing the voices of more marginalized oppositional actors, particularly with respect to activist welfare mothers. In effect, officials took these actions because they believed they could do so without paying a serious political price.

Indeed, government actors often worked hard to conceal their real agenda and motivations with regard to work incentives and welfare mothers. For example, while they claimed to recognize the difficulties welfare mothers faced due to unreasonably low benefits and limited access to jobs that paid enough to live on, they persistently claimed that limiting work-incentive benefits to those who obtained full-time employment was in women's best interests. However, internal ministry documents show that government officials based these decisions first and foremost on the fiscal bottom line. For instance, prior to the introduction of the wIN program, calculations done by the Provincial Secretariat of Social Development showed that the government would save money by offering work incentives for full-time workers but that offering them 
to part-time workers would require additional spending. ${ }^{108}$ According to the documents, a major concern of the government was to prevent recipients from working part-time while also receiving welfare benefits, as this was seen as giving them an avenue for extending their stay on welfare and possibly earning more than someone in low-paid full-time employment. ${ }^{109}$ It was also on fiscal terms that work-incentive projects were deemed successful despite benefitting only a small proportion of welfare mothers, as reflected in a cost/benefit analysis done by the ministry that calculated the net savings to the province accruing from the first three years of the federal-provincial pilot project for sole-support mothers. ${ }^{110}$

Similar stealth strategies were conducted regarding the question of whether work requirements for welfare mothers would be voluntary or mandatory. As mentioned earlier, this was a source of great anxiety for many welfare mothers and was frequently raised by welfare mother groups. ${ }^{111}$ Yet, the government was often less than transparent when responding to this issue, such as in Taylor's ambiguous response when the concern was raised with regard to the sole-support mothers' pilot project. The minister stated that the government did not intend to break up the family unit by taking mothers away from their children, other than in "cases where ... the mothers' child-rearing responsibilities have lessened." 112 Often, however, the ministry responded by reassuring welfare mothers and the public that work-incentive measures were completely voluntary. With respect to Drea's integration and ASPIRE/ESI plans, sole-support mothers were told that they would not be treated differently than before and would receive the same amount of benefits on GWA as they did on FBA. ${ }^{113}$ As Drea's deputy minister put it, "Nobody's trying to force anybody to do anything." ${ }^{114}$ However, as several internal government documents

108. Appendix, 15 November 1978, in John Nywening, Provincial Secretariat for Social Development, to Margaret Birch, memo, 27 November 1978, RG54-3, box ww2, AO.

109. For example, see comsoc, Work Incentives for Recipients.

110. MCSS, Federal-Provincial Pilot Project for Sole Support Mothers: Twelve Month Report, 4 October 1978, Strategic Planning and Policy Secretariat, MCss, RG54-3, box ww2, AO.

111. Thunder Bay was one of the locations that agreed to be a testing ground for the ASPIRE employment strategy mounted by Minister Drea. Exemplifying the kind of reaction that welfare mothers had, Joan Baril, spokesperson for the Thunder Bay group Concerned Moms, suggested that the program was a ploy to shift sole-support mothers onto lower city benefit rates. This caused (as Baril put it) "fear like stone in the heart of mothers ... how to hold on then?" See Brigitte Sutherland, "Welfare Cutbacks," undated reprint of article in Herizons, the Manitoba Women's Newspaper [c. 1983], FBWG file, Women's Movement Archives, Ottawa.

112. Helen Worthington, "Sole Support Mom Wins a Long Fight to Get Off Welfare," Toronto Star, 8 May 1978.

113. For example, see Ontario, Legislative Assembly, Hansard, 32nd Parl, 2nd Sess (31 May 1982) at S-156.

114. Mary Hynes, “Municipalities' Caution Stalls Benefits Transfer,” Globe and Mail, 8 July 
show, officials had from the outset viewed mandatory work requirements as a potential realistic long-term option. They considered the measures introduced (i.e. the pilot project, WIN, and integration and ASPIRE/ESI programs) as "preconditions" or "prerequisites" to the implementation of a mandatory system. ${ }^{115}$ With respect to the ASPIRE program, one internal MCSS document advised that the "initial press releases could stress that some people believe that ... a requirement/expectation [for mandatory work] is needed ... but that the Ministry prefers at this time to implement only employment services and other supports." 116 Toronto Star columnist Michele Landsberg pointed to this lack of transparency at the time, writing that the work-incentive and integration measures introduced by Drea were just "a long slow warm up for the real thing [work for welfare]."117

Ministry officials also sought to minimize the resistance to their proposals by seeking to undermine the political credibility and influence of particular welfare mother groups. For example, Drea raised an alarm among welfare mothers when he announced that sole-support mothers on FBA were to be redefined as employable "for statistical purposes" only, and "to eliminate costly duplication of services," but then remained silent on this issue for the next eleven months. ${ }^{118}$ Commenting at the time, Glenn Drover, a social policy scholar and former official with the Department of Community and Social Services, wrote that Drea's claim that the plan would eliminate costly duplication of services was a "red herring" and that part of the reason welfare recipients were being shifted from the province to the municipalities was to lessen their political influence. ${ }^{119}$

At other times officials used more authoritarian and shaming means of quelling welfare mothers' criticism and resistance to the work-incentive plans. For example, while attending a June 1982 demonstration by welfare mothers against the transfer of FBA recipients to municipal welfare, the minister declared, "We're virtually giving you everything you've asked for - job counseling, training programs, child care, and financial support." When someone shouted that being a mother was a full-time job, Drea replied, "The problem is you don't want to hear. ... I hope that in a few months, if you can get the time

1982.

115. сомsoc, Work Incentives for Recipients; Report on Selected.

116. Report on Selected. See also Ontario, Legislative Assembly, Hansard, 32nd Parl, 2nd Sess (19 May 1982) at S-32-34.

117. Michele Landsberg, "Just Watch How Frankly Drea Talks," Toronto Star, 16 September 1982.

118. "Municipalities' Caution Stalls"; Sutherland, "Welfare Cutbacks." See also "At Whose Expense?," editorial, Toronto Star, 19 May 1982.

119. Glenn Drover, "Frank Drea's Dream a Nightmare, Former Planner Says," Toronto Star, 18 August 1982. 
off work that you will come back and thank us very much for changing the system." ${ }^{120}$ The minister also called out to demonstrators, "If you don't want to be self-sufficient, raise your hand"121 and "I can't believe that the sole-support mothers in this province, even those that congregated on the steps of Queens Park, would spurn the opportunity to become usefully self-supporting." 122 On another occasion, Drea attacked the MAG, claiming that the group was using "propaganda, scare tactics and misinformation" and did not represent most welfare mothers. ${ }^{123} \mathrm{He}$ was also prone to praising the more "cooperative" welfare mothers. In a meeting of the ASPIRE program, for instance, Drea told the women participants gathered that "the public is proud of you for showing you want to work," and he thanked them for "destroy[ing] the myth ... [that] single sole-support parents didn't want to get involved."124

\section{Conclusions}

IN THIS ARTICLE, I HAVE attempted to uncover both the political paradigm underpinning Ontario's work incentives for welfare mothers measures of the 1970 s and early 1980 s and the political practices that led to their being recognized as a reasonable and responsible approach to the problems of welfare mothers. To be clear, these developments were partly the outcome of broader historical shifts such as changes in social norms regarding women's equality and their participation in the labour force, the economic crisis of the mid1970s, and the shift by Ontario's ruling party to supply-side economics and neoliberalism. Yet, as I have argued here, this outcome cannot fully be understood without reference to political struggle. The turn to work incentives for welfare mothers was the result of a complex and longer-term process in which a range of political actors worked to build up an expert technical field that aimed to govern and improve welfare mothers. This assemblage drew from an existing repertoire of research materials, but it was also the outcome of debate over the needs of welfare mothers that involved both key expert (often state)

120. Sole Support Parents Coalition, Newsletter, July 1982, FBwG file, Women's Movement Archives, Ottawa; see also Frances Kelly, “Mothers Protest Benefits Change,” Toronto Star, 10 June 1982.

121. Barbara Sands, "Drea's Words Insult His Ministry," unknown source, n.d., Secretariat on Social Development, Clippings files, 1981-83, RG54-4, box 2, AO. According to this clipping, Drea said, "I have all day and you're going to get sunburned," to which someone in the crowd shouted that they had all day too, to which he replied, "and that's precisely why we want to change the system, because you do have all day." Also see, "Moms Clash with Drea," The Sun, 10 June 1982.

122. Martha Stark et al., "Mothers Have Gall to 'Demand' Benefits," letter to the editor, Toronto Star," 7 July 1982.

123. Robert Stephens, "Mothers' Group Assails New Welfare Program,” Globe and Mail, 18 May 1983.

124. MCSs, news release. 
and oppositional (social movement) actors, including those most affected by the policies. Within this meso context, situated individuals, often government officials, re-posed political questions as matters of technique and, in so doing, limited the debate agenda. Their methods also entailed the forging of alignments with progressive actors, absorbing critique within the realm of expertise, managing dialogue, presenting failure as the outcome of rectifiable deficiencies, and obscuring contradictions. At the same time, many mainstream progressive organizations, adopting the role of "friendly critic," helped to produce knowledge that served to legitimize and maintain the dominant assemblage. Added to this, Ontario officials/trustees fell back on their sovereign power and authority to contain the debate and rule out alternative perspectives, including directing hostility toward welfare mothers groups and "shaming" recipients (wards) and coercing them, even if only implicitly, with threats of taking their children away and/or withdrawing their means of survival.

These programs and the surrounding discourses were anything but benign. They operated as a form of anti-politics that screened out the political and rendered welfare mothers' needs as technicalities. Government officials simply assumed that women with "reduced child-rearing responsibilities" were employable economic actors, like men, ignoring the ways that caring responsibilities and other structures of gender, race, and class inequality were real and ongoing forces in shaping women's lives, daily and over long periods. ${ }^{125} \mathrm{At}$ such moments and in such spaces, inequitable social structures were recast as personal "stressors" or "barriers" that women were expected to manage and overcome individually.

Ann Porter's insights into the rise of neoliberalism and neoconservatism in Canada and its relationship to the women's movement and gender equality raise several important questions about the possible wider implications of these developments. She argues that while some feminist scholars have tended to see certain governing ideologies (such as social liberalism) as having created political space for the women's movement and feminism, more attention should be paid to how dominant ideologies/political projects such as neoliberalism and, especially, neoconservatism have been a response to the successes of the women's movement and its demands. ${ }^{126}$ Indeed, I would suggest that the 1970s turn to employability for single mothers on welfare was such a moment. This struggle was one in which government officials were frequently pitted against single mothers who were pressing for better conditions and equality, and the actions of officials were often clearly designed to contain

125. James Taylor, "Keynote Address by the Honourable James Taylor, Q.C., MCCs, to the 26th Annual Meeting of the Ontario Municipal Social Services Association," 7 June 1976, MCss, F837, box 91, AO.

126. Ann Porter, "Neo-Conservatism, Neo-Liberalism, and Canadian Social Policy: Challenges for Feminism," Women's Studies/Les Cahiers de la Femme 29, 3 (2012): 19-31, esp. 27. 
and thwart their project. Rather than seeing these developments as reflecting and representing a cultural shift toward gender equality, then, we should ask whether they represent a reassertion of neoliberalism and neoconservatism - essentially, introducing authoritarian and patriarchal tools for reproducing gender inequality and male supremacy and for continually re-establishing and strengthening the division between those with power (those who know best) and those on the margins (deemed as deficient and deviant and in need of control, management, and, perhaps, discipline).

Secondly, Porter argues that it is important to reflect not only on the ideologies of neoliberalism and neoconservatism but on their material consequences for diverse populations. Indeed, if we look beyond the rhetoric surrounding the "work incentives plus declining benefits" solution to its material impact, it becomes clear that this policy was not in the best interests of single mothers and their families. ${ }^{127}$ The approach resulted in welfare mothers and their children experiencing a significant drop in income - from 80 per cent of the poverty line in 1975 to 65 per cent of the poverty line in $1982 .{ }^{128}$ By 1983, a single mother on welfare with three children was living on an income that was 56.7 per cent $(\$ 8,400)$ below the poverty line and was only 29.3 per cent of the median income for all families of that composition (i.e. mother with three children) living in Ontario. ${ }^{129}$ Essentially, the Ontario government's "work incentives plus declining benefits" solution was primarily about preventing welfare mothers from establishing their families on solid ground.

Finally, if, as Porter underlines, neoliberalism and neoconservatism are political projects that reassert class power and the power of elite classes, and that this happens not only through "the growing power and wealth of elite classes but through the fragmentation of community and families for those at the lower end," then the project of work incentives for welfare mothers was part and parcel of the neoliberal/neoconservative offensive - a moment in which autonomy and strength was taken away from a social group that was already marginalized, patriarchal hierarchy and control were reproduced, and the power and authority of those at the top of the social and economic hierarchy were enhanced. ${ }^{130}$ This analysis accords with Krystle Maki's critical insights on the impact of Ontario's current social assistance program - her argument being that the program is about not only regulating the poor but increasing the power and authority of the state. ${ }^{131}$

127. Porter, "Neo-Conservatism, Neo-Liberalism."

128. Pat McNenly, “40,000 Children in 'Raw Poverty' Planner Warns," Toronto Star, 29 March 1982.

129. SPCM \& OSDC, And the Poor Get Poorer, 21. Median income is derived from families whose income is drawn largely from wages and salaries (p. 21).

130. Porter, "Neo-Conservatism, Neo-Liberalism," 28.

131. Maki, "Neoliberal Deviants." 
ETM discourse and the employability assemblage are alive and well today in Ontario. Work-incentive/employability measures ("Employment Support" in Ontario Works) are entrenched within the welfare system as the main solution for single mothers, and the system continues to perpetuate the notion that change lies in individual actions and to ignore the existence of the unpaid work that women do in raising children. ${ }^{132}$ While these programs fail to deliver the promised autonomy, security, and independence to vulnerable mothers and their children, feminist critiques of this approach have gained little traction in the recent discussions of welfare reform. ${ }^{133}$ It is important for feminists and members of other progressive movements to engage more critically in this discussion and challenge inequality-producing policy more generally, including those policies designed to "improve" certain "deficient" peoples in society. This also means working in solidarity with those most affected by these policies and advancing alternatives that meaningfully address gender and race inequality, including recognizing and valuing the unpaid work of social reproduction.

Many thanks to Charles Smith and the anonymous reviewers for their helpful comments and suggestions on this paper.

132. For additional information, see Gazso, "Gendering Social Assistance Reform."

133. See Mosher, "Human Capital." 